\title{
Determinant Factors Affecting Performance of Supply Chain in Pulp and Paper Industries During Pandemic Era in Indonesia
}

\author{
Kis Yoga Utomo ${ }^{\text {a }}$ Indra Siswanti ${ }^{\mathrm{b}}$, Nur Azis ${ }^{\mathrm{c}}$, Embun Prowanta $^{\mathrm{d}}$ \\ ${ }^{a}$ Mechanical Engineering Department, Faculty of Engineering, Krisnadwipayana University, Indonesia \\ ${ }^{\mathrm{b}}$ Management Department, Faculty of Economics and Business, Universitas Mercu Buana, Indonesi \\ ${ }^{\mathrm{c}}$ Information System Department, Faculty of Engineering, Krisnadwipayana University, Indonesia \\ ${ }^{\mathrm{d}}$ Management Department, Faculty of Economics and Business, Perbanas Institute, Indonesia \\ a yogautomo760@gmail.com1, ${ }^{\mathrm{b}}$ indra.siswanti@mercubuana.ac.id, ${ }^{\mathrm{c}}$ nurazis@ unkris.ac.id, ${ }^{\mathrm{d}}$ embun.prowanta@ perbanas.id
}

Article History: Received: 10 November 2020; Revised 12 January 2021 Accepted: 27 January 2021; Published online: 5 April 2021

\begin{abstract}
One of the important keys for businesses today to be able to compete is to strengthen their supply chain management system. The impact of a pandemic is felt by all types of businesses, the most important unit of business that also feels the impact of the pandemic is how businesses maintain and even improve the performance of their supply chain management and one of the businesses or industries that is sufficiently affected by the pandemic for its supply chain resilience ispulp and paperindustry. The purpose of this study is to improve the performance of the supply chain, especially in the pulp and paper industry in Indonesia during the pandemic. This study uses two independent variables, namely inventory policies and information sharing and one dependent variable, namely supply chain performance. Data collection in the form of a survey using questionnaire media was carried out on 85 practitioners who work in supply chain units such as production, marketing and logistics. Data collection was carried out from July to September 2020. The results of this study are the conclusion that there is a positive and significant effect of inventory policies and information sharing on supply chain performance. The estimated coefficient of inventory policy on supply chain performance is 0.61 , while the estimated coefficient of information sharing on supply chain performance is 0.24 . The simultaneously effect of the two independent variables on the dependent is 0.72 ..
\end{abstract}

Keywords: inventory policies, information sharing, supply chain performance, pulp and paper, Indonesia

\section{Introduction}

Supply Chain Management (SCM) is a system that connects several players in it, players in the supply chain including suppliers, manufacturers, distributors, retailers to consumers. This system takes the form of a flow from the time the raw material arrives at the factory, is finished production until it is consumed by consumers[10].Supply chain management is a systemic process, with many factors at the operational level that greatly affect the performance of the supply chain [3]. Measuring the success of the supply chain must start by identifying indicators that affect the performance of the supply chain. The ability of an organization to build a map of success parameters and measure supply chain performance is a challenge for any organization [4].Fawcet et al. (2007) provides SCP measurement indicators, namely Inventory costs, transportation costs, on-time delivery, overall customer satisfaction, order fulfillment lead times, and the cost of purchased items [16].In the supply chain cycle, each individual must be able to control his or her duties as well as possible, so that the journey of products and services is smooth, other organizations in the supply chain cycle must be able to monitor the performance of the supply chain of other organizations[5].

Inventory is an important component in an industry. In a manufacturing company, it takes a supply of raw materials, finished products and supplies. Industrial service companies such as hospitals need supplies of drugs, foodstuffs, and medical equipment. Government offices require supplies of administrative materials such as paper, blanks or forms, and other writing equipment[19]. These items are proof that inventory is an important object for any production system that must always be considered. Inventory is an idle resource, which means if an excess supply will lead to wasted investment, however if there is no supply it will be difficult to anticipate fluctuations in demand that can lead to stockout. So a good inventory management is needed to manage the balance between inventory investment and customer service (service level)[11].

In various researches and business practices, either the activities in manufacturing or in distributors, information sharing has proven successful in improving the performance of the supply chain[6]. Information sharing includes customer, logistics, quality, time and market changes [15]. In a discipline that studies the implementation of information sharing, basically information sharing must be able to provide a solution or at least the right answer or an answer according to what is the question of the parties who asking the questions in the 
supply chain cycle, there are two important factors in information sharing, namely the questioner and the party who expecting an answer to their question[13][8]. Information sharing aims to produce a set of tactical and strategic data such as inventory levels, forecasting, sales and promotion and integrated marketing strategies for more than one company, where all these companies form a supply chain cycle[2]. Information sharing allows each individual in the organization to see various opportunities and risks simultaneously starting from the initial stage of the supply chain process to the last stage, namely when the products and services have been received by customers, the management of information sharing in business is very important and plays an integrated role and considered very crucial[12]. The objective of information sharing is to make it efficient and effective throughout the work cycle of the supply chain which in turn will have an impact on organizational performance[7]. Tannady et al. (2020) measures variabel information sharingusing six indicators namely give the information to partners in advance of changing needs, organization's partner share proprietary information, organization's partner keep your organization fully informed about issues that affect its business, organization's partner exchange information that helps the establishment of business planning, organization's partners share business knowledge of core business processes, and keep each other informed about events or changes that might affect the other partners [17]. Another positive thing about information sharing is that information sharing can make a better learning process in an organization, this learning process will make the organization move towards a better direction, information sharing will be very effective if it is supported by the readiness of the organization in providing the reliable of information and communication technology (ICT) [1].

One of the industries affected by the pandemic is pulp and paper industries. The research was conducted to assess supply chain performance and estimate the factors that affect supply chain performance. The research objective is to estimate the partial and simultaneous effect of inventory policy and information sharing variables on supply chain performance, so that the research results can draw conclusions and suggestions that must be made by management to increase supply chain capacity.

\section{Research Methodology}

This research uses quantitative methods both in data collection and data analysis, data collection tools using a questionnaire distributed to 30 respondents for the initial survey and 85 respondents for data processing and analysis. The measurement scale uses an interval scale. At the initial survey stage, data collection aims to ensure that the instrument is valid and reliable. Validity test using Pearson correlation, with valid criteria is $r$ value is greater than the $\mathrm{r}$ table. The reliability test uses the Cronbach alpha value parameter, all indicators are declared reliable if they have an alpha value greater than 0.7 [14][18]. The data analysis used SEM (Structural Equation Modeling) analysis in examining the effect of inventory policy and information sharing partially and simultaneously on supply chain performance.

The variables used in this research are inventory policy $\left(\mathrm{X}_{1}\right)$, information sharing $\left(\mathrm{X}_{2}\right)$ and supply chain performance $(\mathrm{Y})$. Variable $\mathrm{X}_{1}$ uses five measurement indicators namely raw material management, lead time, safety stock policy, appropriate forecasting technique and warehouse management(IP1-IP5) [19].Variable $X_{2}$ uses six measurement indicators, namely give the information to partners in advance of changing needs, organization's partner share proprietary information, organization's partner keep your organization fully informed about issues that affect its business, organization's partner exchange information that helps the establishment of business planning, organization's partner share business knowledge of core business processes, and keep each other informed about events or changes that may affect the other partners (IF1-IF6) [17]. The Y variable uses six measurement indicators, namely inventory costs, transportation costs, on-time delivery, overall customer satisfaction, order fulfillment lead times, and the cost of purchased items (SP1-SP6) [16]. The study population was all practitioners working in the supply chain cycle in the pulp and paper industries in Indonesia. The minimum number of samples of respondents is multiplication of five to ten of the number of indicators [9]. Hipotesis dari penelitian adalah inventory policygives a positive effect on supply chain performance $\left(\mathrm{H}_{1}\right)$, Information sharing gives a positive effect on supply chain performance $\left(\mathrm{H}_{2}\right)$. Inventory policy and information sharing simultaneously affect supply chain performance $\left(\mathrm{H}_{3}\right)$.

\section{Discussion and Analysis}

The analysis and discussion begins with validity and reliability testing, after all data are declared to meet the valid and reliable criteria, the next step is to perform structural equation modeling analysis with SEM. Table 1 shows the results of the validity and reliability tests on 17 indicators of three variables.

Table 1. Data Quality Test (Validity and Reliability)

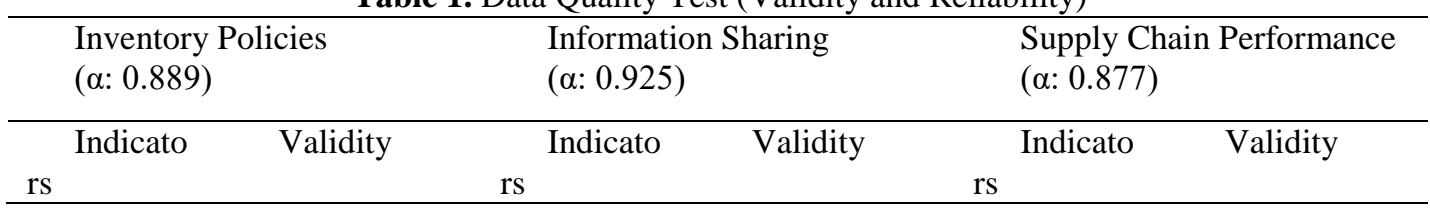




\begin{tabular}{llllll}
\hline IP1 & 0.925 & IF1 & 0.956 & SP1 & 0.817 \\
IP2 & 0.960 & IF2 & 0.923 & SP2 & 0.872 \\
IP3 & 0.832 & IF3 & 0.921 & SP3 & 0.882 \\
IP4 & 0.840 & IF4 & 0.878 & SP4 & 0.965 \\
IP5 & 0.886 & IF5 & 0.910 & SP5 & 0.826 \\
& & IF6 & 0.928 & SP6 & 0.885 \\
\hline
\end{tabular}

The results of the validity and reliability tests in table 1 indicate that all indicators meet the valid and reliable criteria. The cronbach alpha value of the three variables is greater than 0.7 and all $\mathrm{r}$ values of 17 indicators are greater than $r$ table (0.361).The next step is to carry out confirmatory factor analysis (CFA), CFA analysis aims to obtain the estimated coefficient value and t-value of each independent variable on the dependent.Table 2 shows the estimated coefficient and $t$ value of the inventory policy and information sharing variables on supply chain performance.

Table 2. Estimated Coefficient \& T Value

\begin{tabular}{|c|c|c|c|}
\hline${ }_{0} \mathrm{~N}$ & Variable & Estimation Coefficient & $\begin{array}{c}\mathrm{T} \\
\text { Value }\end{array}$ \\
\hline 1 & Inventory Policy & 0.61 & 5.6 \\
\hline 2 & $\begin{array}{l}\text { Information } \\
\text { Sharing }\end{array}$ & 0.24 & 4.2 \\
\hline
\end{tabular}

Table 2 shows that the inventory policy and information sharing variables have a positive effect on supply chain performance. The estimated coefficient of inventory policy is 0.61 with a t-value is 5.6. The estimated coefficient of information sharing is 0.24 with a t-value is 4.2.The next step is a Goodness of Fit (GoF Test), the GoF test is tested on the whole model of the research. The Gof test uses eight parameters such as GFI, RFI, NFI, IFI, CFI, NNFI, RMSEA, and AGFI. Table 3 shows the results of the GoF test.

Table 3. Goodness of fit Test

\begin{tabular}{lrl}
\hline Parameters & Results & \multicolumn{1}{c}{ Criteria } \\
\hline GFI & 0.927 & Good Fit \\
IFI & 0.948 & Good Fit \\
RFI & 0.945 & Good Fit \\
NFI & 0.927 & Good Fit \\
NNFI & 0.912 & Good Fit \\
CFI & 0.962 & Good Fit \\
RMSEA & 0.032 & Good fit \\
AGFI & 0.907 & Good fit \\
\hline
\end{tabular}

Based on the results of the Goodness of Fit test, it is concluded that based on the eight parameters, it is obtained that all parameters meet the good fit criteria, with the results of this test it can be concluded that the research model has met the fit criteria. Based on the results of the CFA analysis which produces a value of estimated coefficient and t-value of each independent variables, it can be concluded that $\mathrm{H} 1$-there is anypositive effect of inventory policy on supply chain performance with an estimated coefficient of 0.61 and t-value 5.6, $\mathrm{X}_{1}$ has a positive and significant effect on $\mathrm{Y}\left(\mathrm{H}_{1}\right.$ accepted). $\mathrm{H}_{2}$ - there is any positive effect of information sharing on supply chain performance with an estimated coefficient of 0.24 and t-value $4.2, \mathrm{X}_{2}$ has a positive and significant effect on $\mathrm{Y}\left(\mathrm{H}_{2}\right.$ is accepted). $\mathrm{H}_{3}$ - there is anypositive effect of inventory policy and information sharing simultaneously on supply chain performance with $\mathrm{R}^{2}$ value is 0.72 and f-value $8.34, \mathrm{X}_{1}$ and $\mathrm{X}_{2}$ simultaneously have a positive and significant effect on $\mathrm{Y}\left(\mathrm{H}_{3}\right.$ accepted $)$.

\section{Conclusion}

Inventory policy and information sharing partially and simultaneously have a positive effect on supply chain performance in the pulp and paper industries in Indonesia during the pandemic era. The better the inventory policy 
a company has, include the level of raw materials, warehouse management, production level to inventory management, will greatly affect the performance of the supply chain. The better the information sharing in one organization or the entire organization in one supply chain cycle, will elevate performance of the supply chain.

Suggestions for company management are to improve various policies at the inventory level such as raw material management, lead time, safety stock policy, appropriate forecasting technique and warehouse management. Good coordination between the production department who understands the capacity of the production floor, the marketing department that forecasts demand and coordination with suppliers is critical to the success of the inventory policy formulation. Another suggestion is that increasing and improving the quality of information sharing will optimize supply chain performance in the pulp and paper industry in Indonesia.

\section{References}

Barak, M., and Rafaeli, S. "Online question-posing and peer-assessment as means for web-based knowledge sharing in learning".International Journal of Human-Computer Studies, vol. 61, no. 1, pp. 84-103, 2004.

Cao, M., and Zhang, Q."Supply chain collaboration: Roles of inter-organizational systems, trust, and collaborative culture". London, Springer, 2013.

Chang, H. H., Tsai, Y. C., and Hsu, C. H."E-procurement and supply chain performance".Supply Chain Management: An International Journal, vol. 18, pp. 34-51, 2013.

Ebru, S., and Gul, D. S."Supply chain performance: Measuring the impact of supply chain orientation and brand equity".Journal of Management, Marketing and Logistics,vol. 5, no. 1, pp. 1-17, 2018.

Gawankar, S., Kamble, S., and Raut, R."Development, measurement and validation of supply chain performance measurement (scpm) scale in Indian retail sector".Benchmarking: An International Journal, vol. 23, no. 1, pp. 25-60, 2016.

Honggeng, Z., and W. C. Benton Jr."Supply chain practice and information sharing".Journal of Operations Management,vol. 25, no. 6, pp. 1348-1365, 2007.

Jamal, A. A."The impact of supply chain collaboration on performance in automotive industry: Empirical evidence". Journal of Industrial Engineering \& Management, vol. 12, No. 2, pp. 241-253, 2019.

Jamel, M. E. A., Nik K. N. M.,and Salniza Md. S.“The significant role of communication, price, and quality in creating a brand trust to achieve purchase behavior antecedents and consequence of consumer brand trust".International Journal of Supply Chain Management,vol. 6, no. 4, pp. 260-268, 2017.

Joseph, F. H., William, C.B., Barry, J. B., and Rolph, E. A."Multivariate Data Analysis". New Jersey, Pearson, 2010.

Lee, H. L., and Billington, C."The evolution of supply chain management models and practices at Hewlett Packard”.Interface, vol. 25, no. 5, pp. 42-63, 1995.

Andry, J. F., Tannady, H. and Nurprihatin, F. "Eliciting Requirements of Order Fulfilment in A Company".IOP Conference Series: Materials Science and Engineering, 771, 2020.

Shahbaz, M. S., Kazi, A. G., Othman, B., Javaid, M., Hussain, K., and Rasi R. Z. R. M."Identification, assessment and mitigation of environment side risks for Malaysian manufacturing".Engineering, Technology \& Applied Science Research, vol. 9, no. 1, pp. 3851-3857, 2019.

Sheizaf, R.,and Daphne, R. R."Information sharing online: A research challenge".International Journal Knowledge and Learning, vol. 1, no. 1, pp. 62-79, 2005.

Tannady, H., Andry, J. F., Sudarsono, B. G. and Krishartanto, Y. "Enterprise Architecture Using Zachman Framework at Manufacturing Company".Technology Reports of Kansai University, vol. 62, no. 4, pp. 1869$1883,2020$.

Singh, A."Understanding supply chain disruption risk with the aid of social networks and information flows analysis".Ph.D. Thesis. Aston University, 2013.

Stanley, E. F., Paul, O., Gregory, M. M., James, C. B., and Matthew, W. M."Information sharing and supply chain performance: The role of connectivity and willingness". Supply Chain Management: An International Journal,vol. 12, no. 5, pp. 358-368, 2007.

Tannady, H., Resdiansyah., Andry, J. F., and Marta, R. F."Exploring the role of ICT readiness and information sharing on supply chain performance in coronavirus disruptions".Technology Reports of Kansai University,vol.62, no. 5, pp. 2581-2588, 2020.

Tannady, H., Erlyana, Y., Nurprihatin, F. "Effects of work environment and self-efficacy toward motivation of workers in creative sector in province of Jakarta, Indonesia". Quality: Access to Success,vol. 20, no. 172, pp. 165-168, 2019.

Reichhart, A., Framinan, J. M., and Holweg, M. "The role of inventory in enabling supply chain responsiveness". IFAC Proceedings, vol. 39, no. 3, pp. 309-314, 2006 